\title{
Suspension-feeding behaviour in tropical bivalve molluscs: Perna viridis, Crassostrea belcheri, Crassostrea iradelei, Saccostrea cucculata and Pinctada margarifera
}

\author{
A. J. S. Hawkins ${ }^{1, *}$, R. F. M. Smith ${ }^{1}$, S. H. Tan ${ }^{2}$, Z. B. Yasin ${ }^{2}$ \\ 'Plymouth Marine Laboratory, Natural Environment Research Council, West Hoe, Plymouth PL1 3DH, United Kingdom \\ ${ }^{2}$ Universiti Sains Malaysia, 11800 Pulau Pinang, Malaysia
}

\begin{abstract}
Filter-feeding behaviours of the mussel Perna viridis and the oysters Crassostrea belcheri, Crassostrea iradelei, Saccostrea cucculata and Pinctada margarifera were compared during natural tidal variations in the concentration ( 6 to 40 dry mg total particulate mass $1^{-1}$ ) and organic content $(6$ to $22 \%$ ) of seston available in the Merbok mangrove system, Malaysia. In P. viridis, C. belcheriand S. cucculata, declining retention efficiencies for the largest available particle size classes of more than 6 to $12 \mu \mathrm{m}$ diameter were associated with an overall organic enrıchment of filtered relative to available matter. As seston availabliity increased, a minumum average of $71 \%$ of the additional filtered matter was rejected by each species as pseudofaeces prior to ingestion. And in all 5 species, preferential rejection as pseudofaeces of filtered particles with higher average inorganic content resulted in the net organic enrichment of ingested relative to filtered matter. In $P$. viridis and $C$. belcheri, the efficiency of that net organic selection declined for seston of lower organic content. Combining all data from each species, absorption efficiencies from ingested organics increased exponentially with the organic content of ingested matter Collective findings suggest that key interrelations between component processes of nutrient acquisition were similar to those that have been established for the modeling of feeding, growth and environmental impact among filter-feeding bivalves from temperate latitudes. However, especially fast growth in $P$. viridis stemmed from higher average ( $\pm 2 \mathrm{SE}$ ) clearance rates $\left(13.2 \pm 7.0 \mathrm{l} \mathrm{h}^{-1} \mathrm{~g}^{-1}\right.$ when particulate organic matter $\left.<1 \mathrm{mg} \mathrm{l}^{-1}\right)$, greater average organic enrichment of filtered relative to available matter $(0.99 \pm 0.67)$ and greater average organic enrichment of ingested relative to filtered matter $(0.63 \pm 0.03)$ than have hitherto been recorded in any species of bivalve filterfeeder. In contrast, P. margarifera was least well adapted for the pre-ingestive selection of organic matter, with no differential retention on the gill and little selective rejection as pseudofaeces, representing at least part of the physiological basis for characteristically slow growth in pearl oysters.
\end{abstract}

KEY WORDS: Filter-feedıng behaviour Particle selection - Seston composition - Perna viridis . Crassostrea belcheri. Crassostrea iradelei Saccostrea cucculata Pinctada margarifera

\section{INTRODUCTION}

Filter-feeding behaviour in bivalves is proving highly responsive to fluctuations in both the abundance and the composition of suspended seston (Hawkins \& Bayne 1992, Bayne 1998). Further understanding of that behaviour is required to establish the role of bivalve shellfish in ecosystem processes (e.g.

•E-mail: a.hawkins@pml.ac.uk
Bayne \& Hawkins 1992, Dame 1993, Herman 1993. Smaal \& Prins 1993) and to predict the carrying capacity for shellfish culture within nearshore environments (e.g. Héral 1993). Findings illustrate a complex set of adaptations which not only help to maximise organic absorption, but also to maintain organic absorption relatively independent of short-term fluctuations in seston abundance and composition, including the 'dilution' of organic matter by silt that is typically resuspended within higher concentrations of natural 
seston (e.g. Hawkins et al. 1996, 1997, Urrutia et al. 1996, Navarro et al. 1997). Selective processes, and the consequences of those processes, are a particularly important feature of that behaviour. And because algal monocultures and other artificial suspensions do not afford utilisation of the full potential for particle selection, an emergent consensus now recognises that ecologically relevant responses are best observed when the bivalves are feeding upon natural seston (FosterSmith 1975, Doering \& Oviatt 1986, Cranford \& Gordon 1992, Iglesias et al. 1992, 1996, Navarro et al. 1992, 1994, Bayne et al. 1993, MacDonald \& Ward 1994, Hawkins et al. 1996, Soletchnik et al. 1996, Urrutia et al. 1996, Bacon et al. 1998, MacDonald et al. 1998).

Recent work in the cockle Cerastoderma edule (Urrutia et al. 1996), the oyster Crassostrea gigas (Soletchnik et al. 1996) and the mussel Mytilus edulis (Hawkins et al. 1996) feeding throughout the same natural tidal. variations in seston availability has (1) identified a common set of equations that summarize functional interrelations between processes of particle filtration, pre-ingestive rejection and organic absorption, and (2) shown that those relations may be used to predict feeding behaviour and net organic absorption rate in all 3 species on the basis of seston abundance and seston organic content alone (Hawkins et al. 1998). These findings establish that similar functional interrelations control feeding responses in $C$. edule, C. gigas and $M$. edulis. We now need to test for the further generality of these key relations, for potential use in a common model that predicts filter-feeding and growth in separate species under different environmental conditions of food availability and composition.

To date, there have been no reports of the responses to variation in seston abundance or composition among filter-feeding bivalve shellfish from tropical latitudes. Yet shellfish dominate many nearshore communities in tropical environments. Work described here was undertaken to study the filter-feeding behaviour of the green mussel Perna viridis L., the mangrove oysters Crassostrea belcheri and Crassostrea iradelei, the rock oyster Saccostrea cucculata, and the pearl oyster Pinctada margarifera. All 5 species are cultured commercially throughout tropical waters (e.g. Rangarajan \& Narasimham 1980, Sivalingam 1982, Yoo et al. 1986, Brohmanonda \& Mutaransit 1988, Jarayabhand \& Thavornyutikarn 1995). To ensure natural behaviour and ecologically meaningful comparisons, responses to natural variations of seston were monitored within the Merbok mangrove system, Malaysia. Findings are used to examine whether functional interrelations that influence feeding responses in tropical species are similar to the common set of relations that have recently been established for use within models of feeding behaviour and growth in filter-feeding bivalves from temperate latitudes (Hawkins et al. 1998). We also compare the feeding behaviour of our studied species with a view to understanding observed differences in growth rate and ecogeographical distribution.

\section{MATERIALS AND METHODS}

Feeding behaviours of the mussel Perna viridis and the oysters Crassostrea belcheri, Crassostrea iradelei, Saccostrea cucculata and Pinctada margarifera were studied in response to natural variations of food availability during 3 complete tidal cycles at Kampong Bukit Kechik in the Merbok mangrove system, about 30 miles $(48 \mathrm{~km})$ north of Penang, Malaysia.

Whereas Crassostrea iradelei had been cultured at Kampong Bukit Kechik, the remaining species were collected from other sites as follows: Perna viridis from Pulau Aman, Penang; Crassostrea belcheri from Telaga Nenas, Perak; and both Saccostrea cucculata and Pinctada margarifera from Muka Head, Penang. Regardless of origin, all specimens were first acclimated to common conditions of $27.0 \pm 1.0^{\circ} \mathrm{C}$ and $32.0 \pm$ $1.0 \%$ while supplied with a copious through-flow of unfiltered natural seawater for $2 \mathrm{wk}$ at the Muka Head Research Station, Universitat Sains Malaysia, Penang. Before experimentation, they were transported to Kampong Bukit Kechik, and placed within immersed plastic trays that were suspended below a raft owned by the Fisheries Research Institute of Penang. Starting 48 h later, and working from that same raft, we monitored feeding responses over the 6 to $8 \mathrm{~h}$ that spanned the rise from low to high tide on each of 9,10 and 11 January 1996. Ranges of tidal rise and fall throughout those $3 \mathrm{~d}$ exceeded $1.8 \mathrm{~m}$.

Samples were collected over separate experimental periods of 1 to $3 \mathrm{~h}$ during each tidal cycle. Species were on occasion exchanged between periods of measurement, allowing $>1$ h to adapt following handling. For each period of measurement, up to 11 individual shellfish were each maintained separately in $1 \mathrm{l}$ plastic trays that were supplied with seawater $\left(27.0 \pm 1.0^{\circ} \mathrm{C}\right)$ pumped from beneath the raft. Rates of seawater supply were first adjusted to ensure that concentrations of suspended particles were not reduced by more than $25 \%$ between the inflow and outflow from each shellfish tray, and then maintained at constant rates which differed between 170 and $450 \mathrm{ml} \mathrm{min}^{-1}$ throughout each experimental period. There were no significant differences between particle sedimentation rates at different flow rates, and maximal flow rates in each shellfish tray of $<0.5 \mathrm{~cm} \mathrm{~s}^{-1}$ were well below rates of $>15 \mathrm{~cm}$ $\mathrm{s}^{-1}$ that have been shown to inhibit filter-feeding in other species of bivalve shellfish (e.g. Wildish \& Saulnier 1993). At each collection time, rate of current 
flow at the experimental site was measured by timing the passage of an immersed piece of coconut husk over $2 \mathrm{~m}$ alongside the raft. Water temperature was also recorded, and salinity measured with a refractometer. In addition, 11 of seawater was sampled from the outflows of each tray containing an experimental individual, including 1 empty 'control' tray. Then, the flow rate through each tray was recorded, and all true faeces and all pseudofaeces collected separately. To obtain sufficient precision in our measures of faecal production and faecal composition, the true faeces or pseudofaeces were each combined from replicate groups of 2 to 3 individual shellfish, before being homogenised by rapid repeat-pipetting. Aliquots of seawater and faecal samples were filtered onto separate pre-weighed and ashed Whatman GF/C filters. All filters were dried at $60^{\circ} \mathrm{C}$ before re-weighing and calculation of the total dry sample weight per filter. Each filter was then ashed at $450^{\circ} \mathrm{C}$ for $4 \mathrm{~h}$ prior to final weighing, allowing further calculation both of the ash (inorganic) and ash-free (organic) masses of each filtered sample.

Seston abundance was measured as the total dry particulate mass (TPM; $\mathrm{mg} \mathrm{l}^{-1}$ ) of all available seston, and seston quality as the organic content of total dry seston (OCS; fraction). Measures of TPM and OCS were undertaken assuming that concentrations measured in the outflow from the empty 'control' tray were roprescntative of the available particulates.

Each water sample from both experimental and control outflows were analysed for both particle count and size distribution. These and other measures were made using a Coulter Channelyser and associated tube with orifice diameter of $100 \mu \mathrm{m}$, recording the particle numbers per $2 \mathrm{ml}$ of sample within each of 32 size channels over the range 3 to $17 \mu \mathrm{m}$ equivalent spherical diameter. Efficiencies with which filtered particles within specific size classes were retained on the gill (REP, fraction) were calculated as:

REP $=$ (inflow particle counts $\mathrm{ml}^{-1}$ within size class outflow particle counts $\mathrm{ml}^{-1}$ within size class)/ (inflow particle counts $\mathrm{ml}^{-1}$ within size class)

where the inflow particle counts were measured within outflow water from the control chamber without an experimental individual.

Clearance rate $\left(\mathrm{CR}_{i} \mathrm{l} \mathrm{h} \mathrm{h}^{-1}\right)$ with which each shellfish species removed particles from seawater was calculated as:

$\mathrm{CR}=$ (number of particles $\mathrm{ml}^{-1}$ within the inflow number of particles $\mathrm{ml}^{-1}$ within the outflow)/ (number of particles $\mathrm{ml}^{-1}$ within the outflow) $\times$ litres of water flow $\mathrm{h}^{-1}$ through tray

Particle retention efficiencies declined for particles larger than about $12 \mu \mathrm{m}$ equivalent spherical diameter (refer to 'Results'). Therefore, to approximate pumping rate as closely as possible, $\mathrm{CR}$ was only calculated for particles of 3 to $8 \mu \mathrm{m}$.

Retention efficiencies (REO, fraction) with which the organic content of filtered particles (OCF; fraction) was enriched compared with the organic content of the all available seston (OCS; fraction) were calculated as:

$$
\mathrm{REO}=(\mathrm{OCF}-\mathrm{OCS}) / \mathrm{OCS}
$$

Other processes of feeding and absorption were calculated according to the basic procedures of Hawkins et al. (1996, 1998), Soletchnik et al. (1996) and Urrutia et al. (1996). All calculations are summarized with acronyms in Table 1 . Note that these calculations assume no significant delay in the deposition of filtered particles, estimating particle availability as the integrated average over corresponding periods of faecal collection. Note also that REO, NOSE (net organic selection efficiency), NOIR (net organic ingestion rate), NOAR (net organic absorption rate), NAEFO (net absorption efficiency from filtered organics) and NAEIO (net absorption efficiency from ingested organics) are net measures; REO, NOSE and NOIR being influenced by particle losses or mucous losses from the shellfish, whereas NOAR, NAEFO and NAEIO are influenced both by mucous losses and by metabolic faecal losses.

Following all experimentation, the soft tissues were excised from each shelufish and dried at $60^{\circ} \mathrm{C}$ before measuring the total soft tissue dry weight. Feeding responses were standardised to those for an equivalent individual of $1 \mathrm{~g}$ soft tissue dry weight as follows: $Y_{\mathrm{s}}=$ $\left(W_{\mathrm{s}} / W_{\mathrm{e}}\right)^{b} Y_{\mathrm{e}}$, where $Y_{\mathrm{s}}$ is the standardised parameter, $W_{\mathrm{s}}$ is the standard weight $(1 \mathrm{~g}), W_{\mathrm{e}}$ is the weight or length of the experimental individual, $Y_{e}$ is the uncorrected parameter, and $b$ is the average size exponent of 0.62 for feeding processes in a variety of suspensionfeeding shellfish (Bayne \& Newell 1983). This standard weight of $1 \mathrm{~g}$ soft tissue dry weight compared with averages $( \pm 2 \mathrm{SE}$ ) for all experimental individuals of each species as follows: $0.40 \pm 0.03 \mathrm{~g}$ for Perna viridis, $1.02 \pm 0.07 \mathrm{~g}$ for Crassostrea belcheri, $0.91 \pm 0.11 \mathrm{~g}$ for Crassostrea iradelei, $0.48 \pm 0.08 \mathrm{~g}$ for Saccostrea cucculata and $0.86 \pm 0.24 \mathrm{~g}$ for Pinctada margarifera.

It was not possible to study the feeding behaviour of all 5 species simultaneously. This meant that measures were made over different average periods of food availability (TPM; $\mathrm{mg} \mathrm{l}^{-1}$ ). However, measures in Perna viridis and Crassostrea belcheri were undertaken together over a common range of TPM from 7 to $15 \mathrm{mg}$ $\mathrm{I}^{-1}$, and measures in Saccostrea cucculata and Pinctada margarifera were undertaken together over a similar common range of TPM from 10 to $23 \mathrm{mg} \mathrm{l}^{-1}$. Measures in Crassostrea iradelei were made over a limited range of TPM from 8 to $9 \mathrm{mg} \mathrm{l}^{-1}$. Measures of feeding behaviour were each made upon a different replicate group 
Table 1. Definitions and descriptions of the calculation of separate components of feeding behaviour

\begin{tabular}{|c|c|c|c|}
\hline Parameter & Acronym & Unit & Calculation \\
\hline Clearance rate $^{a}$ & $C R$ & $1 \mathrm{~h}^{-1}$ & $\begin{array}{l}\text { (number of particles } \mathrm{ml}^{-1} \text { within the inflow }- \text { number of particles } \mathrm{ml}^{-1} \\
\text { within the outflow)/(number of particles } \mathrm{ml}^{-1} \text { within the outflow) } x \\
\text { litres water flow } \mathrm{h}^{-1} \text { through tray }\end{array}$ \\
\hline Filtration rate & FR & Total $\mathrm{mg} \mathrm{h}^{-1}$ & $\begin{array}{l}\text { (mg inorganic matter egested both as true faeces and } \\
\left.\text { pseudofaeces } h^{-1}\right) /(1-O C F)\end{array}$ \\
\hline $\begin{array}{l}\text { Retention efficiency } \\
\text { for filtered particles }\end{array}$ & REP & Fraction & $\begin{array}{l}\text { (inflow particle counts } \mathrm{ml}^{-1} \text { within size class - outflow particle counts } \\
\mathrm{ml}^{-1} \text { within size class)/(inflow particle counts } \mathrm{ml}^{-1} \text { within size class) }\end{array}$ \\
\hline $\begin{array}{l}\text { Retention efficiency for } \\
\text { filtered organic matter }\end{array}$ & $\mathrm{REO}$ & Fraction & $\begin{array}{l}\text { (OCF - organic fraction within total particulates available in tray } \\
\text { inflow)/organic fraction within total particulates available in tray } \\
\text { inflow }\end{array}$ \\
\hline $\begin{array}{l}\text { Organic content of } \\
\text { filtered matter }\end{array}$ & OCF & Fraction & $\begin{array}{l}\text { (mg particulate organic matter } \mathrm{l}^{-1} \text { within tray inflow }- \text { mg particulate } \\
\text { organic matter } \mathrm{I}^{-1} \text { within tray outflow)/( } \mathrm{mg} \text { total particulate matter } \mathrm{I}^{-1} \\
\text { within tray inflow - mg total particulate matter } \mathrm{l}^{-1} \text { within tray outflow) }\end{array}$ \\
\hline Rejection rate & $\mathrm{RR}$ & Total $\mathrm{mg} \mathrm{h}^{-1}$ & mg total pseudofaeces egested $h^{-1}$ \\
\hline $\begin{array}{l}\text { Net organic selection } \\
\text { efficiency }\end{array}$ & NOSE & Fraction & $\begin{array}{l}1-\text { (organic fraction within pseudofaeces)/(organic fraction within } \\
\text { total particulates available in tray inflow) }\end{array}$ \\
\hline Net organic ingestion rate & NOIR & $m g h^{-1}$ & $(F R \times O C F)-(R R \times$ organic fraction within pseudofaeces $)$ \\
\hline Net organic absorption rate & NOAR & $\mathrm{mg} \mathrm{h}^{-1}$ & $\begin{array}{l}\text { NOIR }-\left[\left(\text { mg total true faeces egested } h^{-1}\right) \times \text { (organic fraction within }\right. \\
\text { true faeces })]\end{array}$ \\
\hline $\begin{array}{l}\text { Net absorption efficiency } \\
\text { from filtered organics }\end{array}$ & NAEFO & Fraction & $\mathrm{NOAR} /(\mathrm{FR} \times \mathrm{OCF})$ \\
\hline $\begin{array}{l}\text { Net absorption efficiency } \\
\text { from ingested organics }\end{array}$ & NAEIO & Fraction & NOAR/NOIR \\
\hline $\begin{array}{l}\text { Organic content of } \\
\text { ingested matter }\end{array}$ & $\mathrm{OCl}$ & Fraction & NOIR/(FR - RR $)$ \\
\hline
\end{tabular}

of 2 to 3 individuals (refer above), and differed in number $(\mathrm{n})$ between species, with $\mathrm{n}=12$ in $P$. viridis and $C$. belcheri, $\mathrm{n}=6$ in $S$. cucculata and Pinctada margarifera, and $\mathrm{n}=7$ in $C$. iradelei. For all 5 species, average performance is compared, and the natural variation between measures is used to compare functional interrelations between separate component processes of feeding physiology. In $P$. viridis and $C$. belcheri, the range of food availability and number of measures were sufficient to identify influences of TPM on feeding behaviour (refer to 'Results'). Where present data did not allow resolution of the exact form of relations, equations were fitted on the basis of a common set of relations that have previously been shown to satisfactorily predict responses observed in other suspensionfeeding bivalve molluscs (Hawkins et al. 1997). All statistical tests and procedures used in these analyses and in the presentation of data were undertaken using SYSTAT for Windows, Version 7 (SYSTAT Inc., Evanston, IL, USA). Variables were only included as additional predictors in multiple regression if the probability of their correlation with residuals was less than $2.5 \%$. To further avoid constructing multicollinear models with unstable regression coefficient estimates, we also excluded any variable with a tolerance of $<0.1$ (calculated as 1 minus the squared multiple correlation between a predictor and the other predictors in a model).

\section{RESULTS}

\section{Seston availability}

Throughout all 3 tidal cycles, natural seston availability measured as TPM ( $\mathrm{mg} \mathrm{I}^{-1}$ ) varied from 6 to $40 \mathrm{mg} \mathrm{l}^{-1}$. The temporal pattern of variation in TPM was different on each day, and did not correlate $(\mathrm{p}>$ 0.05 ) with current speed, which ranged from 0.01 to $0.5 \mathrm{~m} \mathrm{~s}^{-1}$. Surface water temperature and salinity throughout all measurements averaged ( \pm maximum range) $27.3 \pm 0.8^{\circ} \mathrm{C}$ and $27.9 \pm 1.5 \%$, respectively. Combining the data from all measures of seston availability and quality, Fig. 1 illustrates how the OCS (fraction) decreased from a maximum of 0.22 to a minimum of 0.09 with increasing TPM up to $40 \mathrm{mg} \mathrm{l}^{-1}$, according 
to a negative relation that was best described by the equation

$$
\text { OCS }=0.25(0.18,0.34) \times \mathrm{TPM}^{-0.26( \pm 0.14)}
$$

where $\mathrm{r}^{2}=0.24$, residual $\mathrm{df}=43, \mathrm{p}=0.001$, and bracketed values indicate $95 \%$ confidence limits.

\section{Average feeding behaviour}

Average ( $\pm 2 \mathrm{SE}$ ) REP (fraction) within separate $2 \mathrm{~mm}$ size classes that averaged $4,6,8,10,12,14$ and $16 \mu \mathrm{m}$ equivalent spherical diameter are illustrated for each species in Fig. 2. REPs of 0.25 to 0.35 for the smaller particles of less than about $8 \mathrm{~mm}$ equivalent spherical diameter were essentially similar in all 5 species (Fig. 2). However, REPs for the largest particle size class with an average diameter of $16 \mu \mathrm{m}$ were significantly lower than for the smallest particles with an average diameter of $4 \mu \mathrm{m}$ in Perna viridis $(t=2.51$, residual $\mathrm{df}=13, \mathrm{p}=0.03)$, Crassostrea belcheri $(t=$ 2.73 , residual $\mathrm{df}=25, \mathrm{p}=0.01$ ) and Crassostrea iradelei $(t=7.08$, residual $\mathrm{df}=18, \mathrm{p}=0.000001)$. These reductions appeared to begin for particles larger than about $12 \mu \mathrm{m}$ diameter in $P$. viridis and C. belcheri, and for particles larger than only about $6 \mu \mathrm{m}$ diameter in $C$. iradelei (Fig. 2). No such reductions were apparent in either S. cucculata or P. margarifera ( $p>0.05$ ).

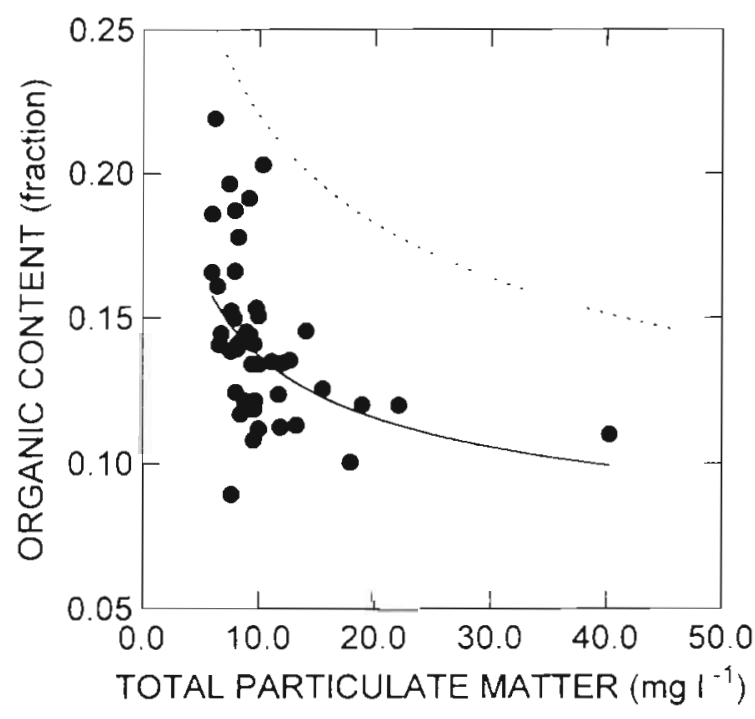

Fig. 1. Relationship between the organic content (OCS; fraction) and total particulate mass (TPM; $\mathrm{mg} \mathrm{l}^{-1}$ ) of seston collected over 3 separate tides in the Merbok mangrove estuary, Malaysia. Both lines were fitted by least squares; the solid line to illustrated data from the Merbok mangrove estuary (refer to 'Results' for the equation), and the dashed line to data from the bay of Marennes-Oléron, France [where OCS $=0.41(0.29$, $0.56) \times \mathrm{TPM}^{-0.27( \pm 0.09)}$; from Hawkins et al. (1996)]

Table 2 summarises average ( $\pm 2 \mathrm{SE}$ ) measures of feeding physiology computed over the full range of seston

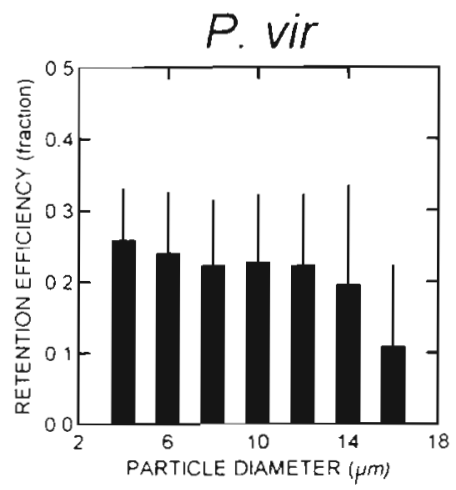

S. cucc

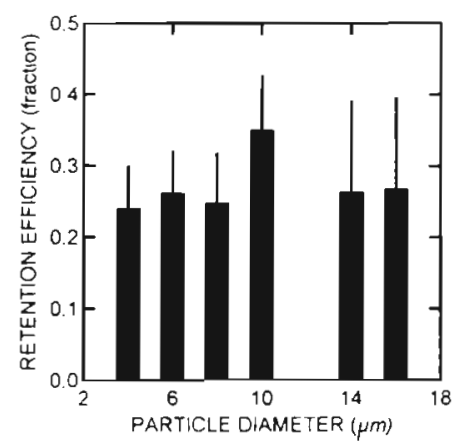

C. bel

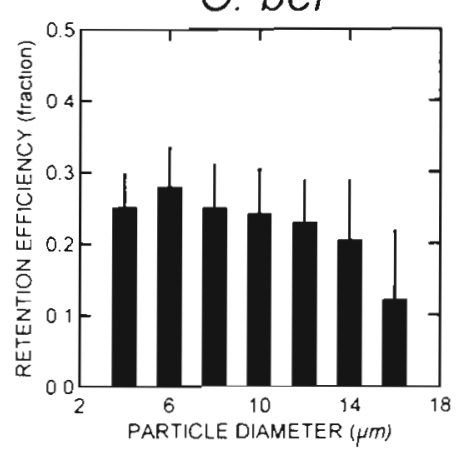

P. marg

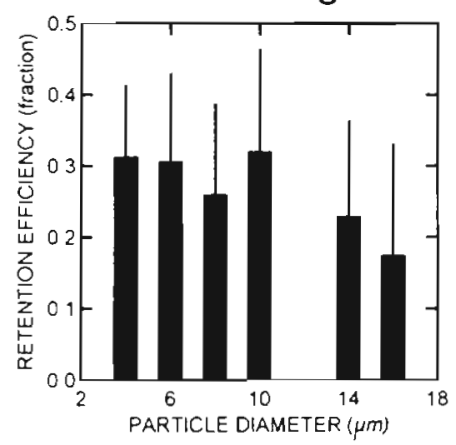

C. irad

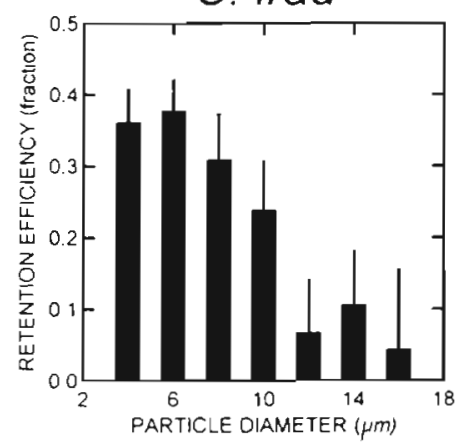

Fig. 2. Perna viridis, Crassostrea belcheri, $C$. iradelei, Saccostrea cucculata and Pinctada margarifera. Retention efficiencies (\%) for particles within size classes of $2 \mathrm{~mm}$ equivalent spherical diameter that ranged from 2 to $18 \mathrm{~mm}$ within the natural seston filtered by each shellfish species in the Merbok mangrove estuary, Malaysia. Data represent the average $\{ \pm 2 \mathrm{SE}\}$ of between 8 and 31 replicate measures per species 
Table 2. Average $\left( \pm 2 \mathrm{SE}\right.$ ) clearance rates for particles of between 3 and $8 \mu \mathrm{m}$ diameter $\left(\mathrm{CR}_{i} \perp \mathrm{h}^{-1}\right)$, net organic retention efficiencies (REO, fraction), net organic selection efficiencies (NOSE, fraction), net organic ingestion rates (NOIR; $\mathrm{mg}_{\text {organics }} \mathrm{g}^{-1} \mathrm{~h}^{-1}$ ) and net organic absorption rates (NOAR; $\mathrm{mg}$ organics $\mathrm{g}^{-1} \mathrm{~h}^{-1}$ ) recorded for each species. All data are standardised for shellfish of $1 \mathrm{~g}$ dry soft tissue weight

\begin{tabular}{|lcccrc|}
\hline Species & CR & REO & NOSE & NOIR & NOAR \\
\hline Perna viridis & $7.2 \pm 3.1$ & $+0.99 \pm 0.67$ & $0.63 \pm 0.03$ & $24.8 \pm 3.6$ & $21.5 \pm 3.4$ \\
Crassostrea belcheri & $4.6 \pm 1.0$ & $+0.35 \pm 0.21$ & $0.39 \pm 0.04$ & $9.5 \pm 1.4$ & $6.0 \pm 0.9$ \\
Crassostrea iradelei & $4.1 \pm 1.5$ & $+0.36 \pm 0.23$ & $0.39 \pm 0.03$ & $7.2 \pm 1.6$ & $4.7 \pm 1.2$ \\
Saccostrea cucculata & $4.9 \pm 1.2$ & $+0.04 \pm 0.24$ & $0.38 \pm 0.09$ & $6.9 \pm 1.7$ & $4.0 \pm 1.5$ \\
Pinctada margarifera & $5.5 \pm 1.3$ & $-0.11 \pm 0.17$ & $0.22 \pm 0.09$ & $2.0 \pm 1.6$ & $1.3 \pm 0.9$ \\
\hline
\end{tabular}

availability for each studied species. Compared with the 4 oyster species, Perna viridis showed the highest average values for CR $\left(\mathrm{h} \mathrm{h}^{-1}\right)$, REO (fraction), NOSE (fraction), NOIR (mg organics $\mathrm{h}^{-1}$ ) and NOAR (mg organics $\mathrm{h}^{-1}$ ) (Table 2). In particular, comparisons of REO indicate that the organic content of matter filtered by $P$. viridis was virtually double that in the total available seston. In contrast, there was no such enrichment in either Saccostrea cucculata or Pinctada margarifera, and although significant in Crassostrea belcheri and Crassostrea iradelei, average percentage increases were only about one-third that in $P$. viridis (Table 2). Similarly, although all 4 species of oysters selectively enriched the organic content of ingested matter relative to filtered matter, their average NOSEs were less than $(0.39 / 0.63) \times 100=62 \%$ of that in $P$. viridis (Table 2 ). The result was that average NOAR in $P$. viridis was 3 to 5 times greater than in the Crassostrea and Saccostrea spp., and 16 times greater than in P. margarifera (Table 2).

\section{Responses associated with changing seston availability}

CR for particles of between 3 and $8 \mu$ m diameter $\left(1 \mathrm{~h}^{-1}\right)$ in Perna viridis decreased from maxima of more than $15 \mathrm{l} \mathrm{h}^{-1}$ to minimal values of less than $5 \mathrm{l} \mathrm{h}^{-1}$ with the increasing availability of POM ( $\mathrm{mg} \mathrm{l}^{-1}$ ) up to $2.5 \mathrm{mg}$ $\mathrm{I}^{-1}$, as is illustrated in Fig. 3 according to a relation that was best described by the following allometric equation:

$$
\mathrm{CR}=12.2(9.6,15.4) \times \mathrm{POM}^{-0.90( \pm 0.54)}
$$

where $r^{2}=0.33$, residual $d f=22$ and $p=0.003$. Multiple stepwise regression indicated that neither TPM nor OCS explained any $(p>0.05)$ of the remaining variance in $C R$. No relation was evident between $C R$ and either TPM, OCS or POM in Crassostrea belcheri ( $\mathrm{p}>$ 0.05 ), despite being measured over the same ranges of seston availability as in $P$. viridis. Nor was any such relation evident in any of the 3 remaining oyster species $(p>0.05)$.
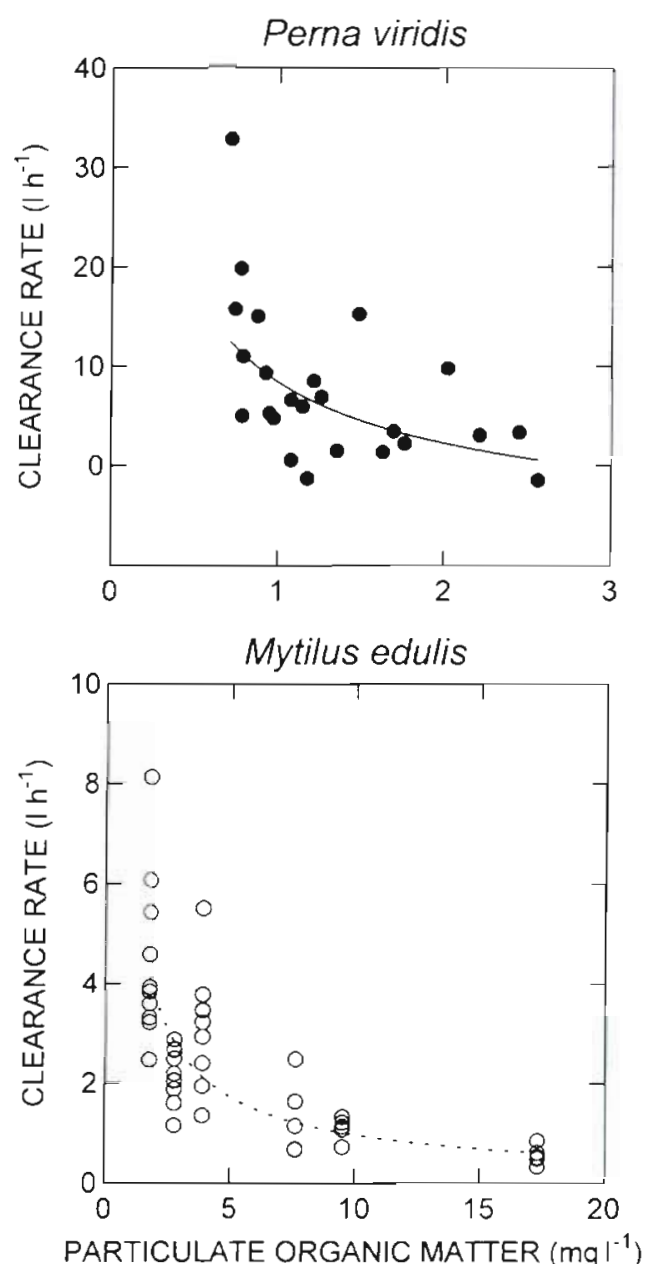

Fig. 3. Perna viridis and Mytilus edulis. Short-term responses in clearance rate for particles of between 3 and $8 \mu \mathrm{m}$ diameter $\left(C R_{i} l \mathrm{~h}^{-1}\right)$ to the particulate organic matter within natural seston ( $\mathrm{POM}_{\text {; }}$ mg $\mathrm{l}^{-1}$ ) available to $P$. viridis in the Merbok mangrove estuary, Malaysia. The solid line was fitted by least squares (refer to 'Results' for equation). Data are also presented for $M$. edulis [where $C R=4.2(3.2,5.5) \times \mathrm{POM}^{-0.84(x 0.08)}$; from Hawkins et al. (1996)]. All data are standardised to $1 \mathrm{~g}$ dry soft tissue weight, and represent separate replicate measures upon individual mussels 

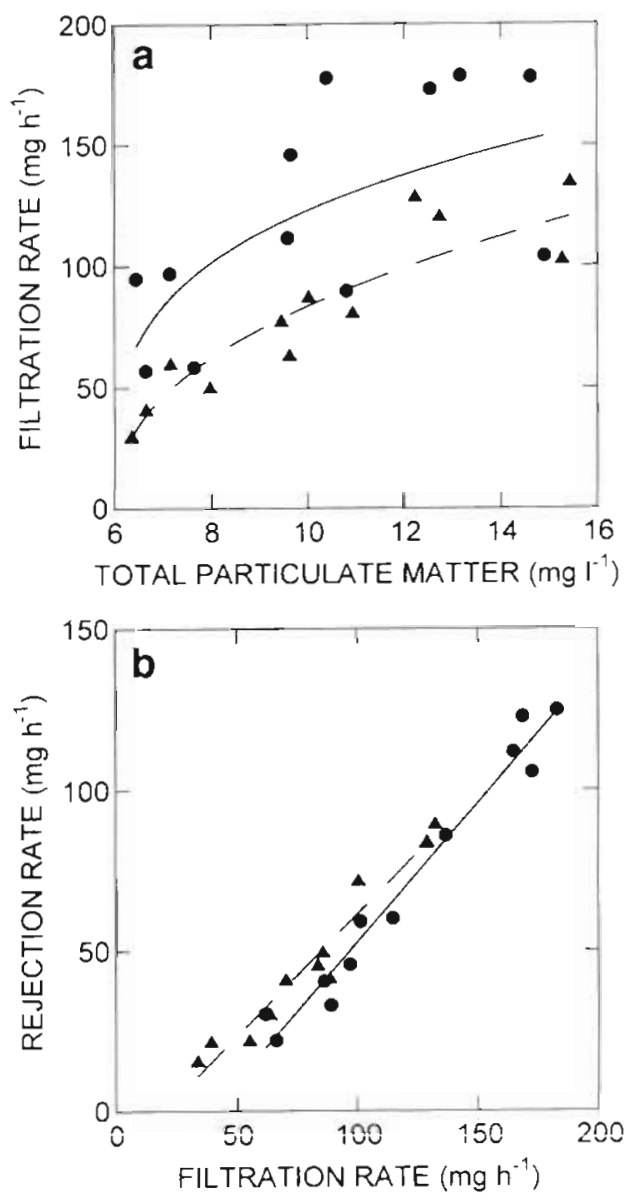

Fig. 4. Perna viridis and Crassostrea belcheri. Short-term responses in (a) filtration rate $\left(\mathrm{FR}_{;} \mathrm{mg} \mathrm{h}^{-1}\right)$ to the total particulate matter within available seston (TPM; $\mathrm{mg} \mathrm{l}^{-1}$ ), and (b) the relation between rejection rate $\left(R R ; \mathrm{mg} \mathrm{h}^{-1}\right)$ and $\mathrm{FR}$ in both $P$. viridis $\left(\bullet_{,}-\right)$and $C$. belcheri $\left(\mathbf{\Lambda}_{,}-{ }_{-}\right)$feeding upon natural seston in the Merbok mangrove estuary, Malaysia. Lines were fitted by least squares (refer to 'Results' for equations). All data are standardised to $1 \mathrm{~g}$ dry soft tissue weight, and represent the average for single measures upon separate replicate groups, each of 2 to 3 shellfish

Filtration rates (FR; total $\mathrm{mg} \mathrm{h}^{-1}$ ) in both Perna viridis and Crassostrea belcheri increased with TPM as is illustrated in Fig. 4 according to relations that were described by the following allometric equations (cf. Hawkins et al. 1997):

\section{Perna viridis}

$\mathrm{FR}=13.8( \pm 3.9) \times \mathrm{TPM}^{0.91( \pm 0.59\}}$

where $r^{2}=0.49$, residual $\mathrm{df}=10$ and $\mathrm{p}=0.01$; and

\section{Crassostrea belcheri}

$F R=2.8( \pm 2.4) \times \mathrm{TPM}^{143( \pm 0.38)}$

where $r^{2}=0.85$, residual $d f=10$ and $p=0.00002$.

There was no indication that either REP or REO varied with TPM, OCS or FR ( $p>0.05)$. But in all 5 species,
FR was the main determinant of pseudofaecal rejection rate ( $R R_{\text {; }}$ total $\mathrm{mg} \mathrm{h}^{-1}$ ) as illustrated for Perna viridis and Crassostrea belcheri in Fig. 4 according to relations that were best described by the following linear relations:

\section{Perna viridis}

$\mathrm{RR}=-33.5( \pm 12.6)+0.87( \pm 0.10) \mathrm{FR}$

where $r^{2}=0.97$, residual $\mathrm{df}=10$ and $\mathrm{p}=0.00000001$;

Crassostrea belcheri

$\mathrm{RR}=-14.6( \pm 9.6)+0.76( \pm 0.11) \mathrm{FR}$

where $r^{2}=0.95$, residual $\mathrm{df}=10$ and $\mathrm{p}=0.00000006$

Crassostrea iradelei

$\mathrm{RR}=-11.0( \pm 6.8)+0.75( \pm 0.11) \mathrm{FR}$

where $r^{2}=0.97$, residual $d f=6$ and $p=0.000008$;

Saccostrea cucculata

$\mathrm{RR}=-9.7( \pm 15.8)+0.71( \pm 0.24) \mathrm{FR}$

where $r^{2}=0.89$, residual $\mathrm{df}=4$ and $\mathrm{p}=0.004 ;$ and

Pinctada margarifera

$\mathrm{RR}=-1.1( \pm 4.3)+0.81( \pm 0.14) \mathrm{FR}$

where $\mathrm{r}^{2}=0.97$, residual $\mathrm{df}=4$ and $\mathrm{p}=0.0003$.

These equations indicate that for every measured increment in FR, a minimum average of $71 \%$ of the additional filtered matter was rejected as pseudofaeces, and which averaged as much as $87 \%$ of that additional filtered matter in $P$. viridis.

NOSE (fraction) in Perna viridis, Crassostrea belcheri and Saccostrea cucculata increased with OCS as is illustrated in Fig. 5 according to relations that were

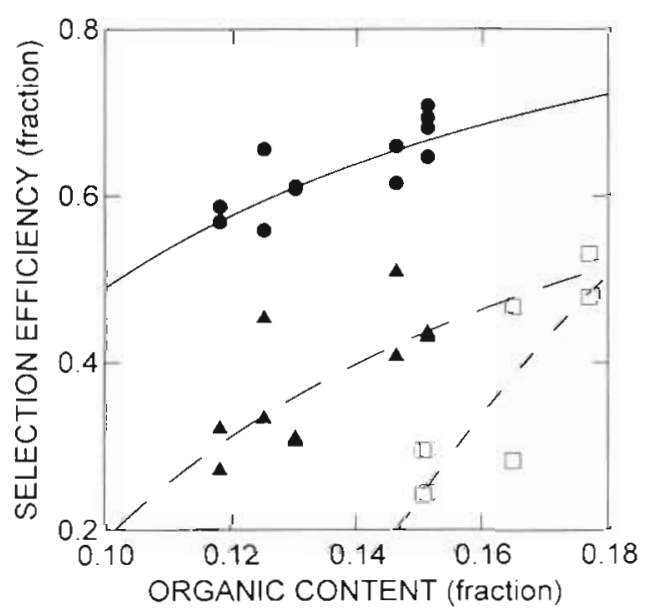

Fig. 5. Perna viridis, Crassostrea belcheri and Saccostrea cucculata. Short-term responses in net organic selection efficiency (NOSE; fraction) to the organic content of natural seston (OFS, fraction) available to $P$. viridis $(-,-)$, C. belcheri $\left(\Lambda_{1}--\right.$ ) and $S$. cucculata ( $\left.\square,---\right)$ in the Merbok mangrove estuary, Malaysia. Lines were fitted by least squares (refer to 'Results' for equations). All data are standardised to $1 \mathrm{~g}$ dry soft tissue weight, and represent the average for single measures upon separate replicate groups, each of 2 to 3 shellfish 
described by the following hyperbolic equations (cf. Hawkins et al. 1997):

Perna viridis

NOSE $=1.01( \pm 0.18)-[0.052( \pm 0.024) \times(1 /$ OFS $)]$

where $\mathrm{r}^{2}=0.63$, residual $\mathrm{df}=10$ and $\mathrm{p}=0.002$;

Crassostrea belcheri

NOSE $=0.92( \pm 0.31)-[0.073( \pm 0.042) \times(1 / \mathrm{OFS})]$

where $r^{2}=0.54$, residual $\mathrm{df}=10$ and $\mathrm{p}=0.006$; and

Saccostrea cucculata

NOSE $=1.84( \pm 0.90)-[0.24( \pm 0.15) \times(1 /$ OFS $)]$

where $r^{2}=0.72$, residual $d f=10$ and $p=0.03$.

Multiple stepwise regression confirmed that FR did not explain a significant proportion of the remaining variance for NOSE in any of these 3 species $(p>0.05)$.

Combining all data from each species, NAEIO (fraction) increased with the organic content of ingested matter ( $\mathrm{OCl}$; fraction) in a strong common relation that was best described by the exponential equation:

NAEIO $=0.89( \pm 0.06) \times\left(1-e^{-8.58( \pm 3.36) \mid O C I-0.13( \pm 003)\}}\right)$ where $\mathrm{r}^{2}=0.87$, residual $\mathrm{df}=40$ and $\mathrm{p}=0.00000003$

This relation is illustrated in Fig. 6, showing how NAEIO increased from as low as 0.3 to maximal values of more than 0.8 at the highest $\mathrm{OCI}$.

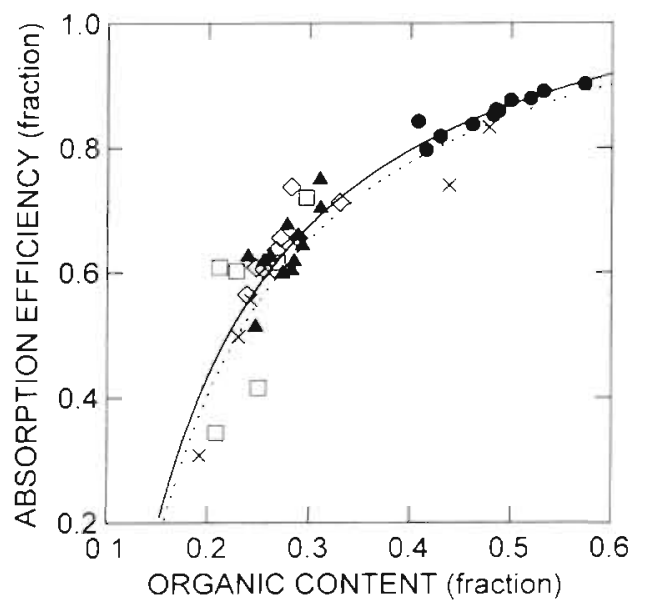

Fig. 6. Perna viridis, Crassostrea belcheri, Crassostrea iradelei, Saccostrea cucculata, Pinctada margarifera and Mytilus edulis. Short-term responses in net absorption efficiency from ingested organics (NAEIO; fraction) to the organic content of matter ingested (OCl; fraction) by $P$. viridis $(\bullet), C$. belcheri $(\mathbf{\Lambda})$, C. iradelei ( $\diamond), S$. cucculata ( $\square$ ) and P. margarifera ( $\times$ ) feeding upon natural seston in the Merbok mangrove estuary, Malaysia. The solid line was fitted by least squares to all data combined (refer to 'Results' for equation). The dotted line illustrates the same relation for $M$. edulis [NAEIO= $1.15( \pm 0.03)-0.149( \pm 0.004) \times(1 / \mathrm{OCI})]$ feeding upon natural seston from the bay of Marennes-Oléron, France (from Hawkins et al. 1997). All data are standardised to $1 \mathrm{~g}$ dry soft. tissue weight, and represent the average for single measures upon separate replicate groups, each of 2 to 3 shellfish

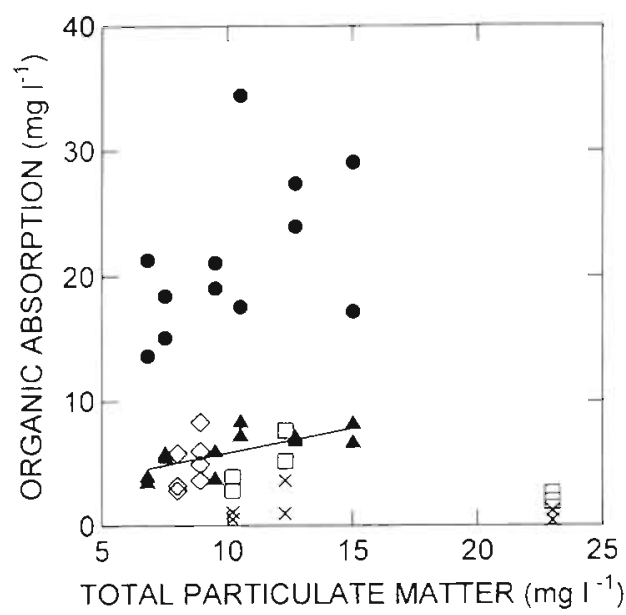

Fig. 7 Perna viridis, Crassostrea belcheri, Crassostrea iradelei, Saccostrea cucculata and Pinctada margarifera. Shortterm responses in net organic absorption rate (NOAR; $\mathrm{mg} \mathrm{h}^{-1}$ ) to the total particulate mass $\left(\mathrm{TPM}_{\mathrm{i}} \mathrm{mg} \mathrm{l}^{-1}\right.$ ) of natural seston available to $P$. viridis $(\bullet), C$. belcheri $(\wedge), C$. iradelei $(\diamond), S$. cucculata $(\square)$ and $P$. margarifera $(x)$ feeding upon natural seston in the Merbok mangrove estuary, Malaysia. The line was fitted by least squares to data for $C$. belcheri alone (refer to 'Results' for equation). All data are standardised to $1 \mathrm{~g}$ dry soft tissue weight, and represent the average for single measures

upon separate replicate groups, each of 2 to 3 shellfish

Despite significant ranges of food availability, shortterm responses in NOAR $\left(\mathrm{mg} \mathrm{h}^{-1}\right)$ did not vary with TPM in either Perna viridis, Saccostrea cucculata or Pinctada margarifera ( $p>0.05)$. Alternatively, as is illustrated in Fig. 7, a significant positive relation between NOAR and TPM suggests that absorption would have increased at higher food availabilities in Crassostrea belcheri.

\section{DISCUSSION}

The form and slope of the relation between OCS and TPM of seston available at our experimental site in the Merbok mangrove estuary were similar to those observed in the bay of Marennes-Oléron, France (refer to 'Results' and Fig. 1). This suggests 'dilution' of organic matter by the silt that is typically resuspended within higher concentrations of natural seston (e.g. Widdows et al. 1979). However, OCS at any given TPM in the Merbok estuary was almost half that observed in the bay of Marennes-Oléron (Fig. 1). We are not aware of other comparable data from tropical waters.

Filter-feeding behaviour in bivalve molluscs is highly flexible in response to changes in both the amount and composition of available seston (Hawkins \& Bayne 1992, Bayne 1998). In particular, feeding rate decreases in exponential relation with increasing con- 
centrations of POM, presumably because the gut becomes saturated with organics (e.g. Iglesias et al. 1992, Hawkins et al. 1997) (Fig. 3). This means that high feeding rates are observed at low availabilities of organically rich food as in artificial diets comprised mainly of cultured unicellular alga or algae (e.g. Møhlenberg \& Riisgärd 1979, Riisgärd 1988, Jørgensen 1996. Hawkins et al. 1997). But the reverse may occur for natural seston of lower $(<25 \%)$ OCS, for which feeding rate has been observed to increase to maximal rates at higher concentrations (e.g. Iglesias et al. 1992, Newell \& Shumway 1993, Hawkins et al. 1996), only decreasing upon clogging of the gills at the very greatest loads (Widdows et al. 1979, Barillé et al. 1997). This is because OCS typically decreases with the increasing TPM of natural seston, due to 'diluting' effects of suspended silt. Further, unlike monocultures of alga, natural seston affords the opportunity for particle selection, which is most efficient at those maximal rates of feeding (Hawkins et al. 1998). Given these selective processes, there is no guarantee that the same maximal feeding rates occur when shellfish filter natural particle mixtures as when they filter cultured alga or algae. It is therefore important that behaviour be compared under similar feeding conditions. In the present study of responses to natural seston, average ( $\pm 2 \mathrm{SE}$ ) CR $\left(1 \mathrm{~g}^{-1} \mathrm{~h}^{-1}\right)$ for particles of between 3 and $8 \mu \mathrm{m}$ diameter in all 5 species ranged from $41 \pm 1.5$ to $7.2 \pm 3.1$ ! $\mathrm{g}^{-1} \mathrm{~h}^{-1}$ (Table 2). Comparable averages across full ranges of experimental food availabilities have not exceeded $3.0 \mathrm{l} \mathrm{g}^{-1} \mathrm{~h}^{-1}$ in all previous studies for a variety of temperate species feeding upon natural seston, including Cerastoderma edule (Navarro et al. 1994), Crassostrea gigas (Soletchnik et al. 1996), Mya arenaria (Bacon et al. 1998), Mytilus edulis (Bayne et al. 1993, Newell \& Shumway 1993, Hawkins et al. 1996). Mytilus galloprovincialis (Navarro et al. 1996) and Placopecten magellanicus (Cranford \& Gordon 1992. MacDonald \& Ward 1994, Bacon et al. 1998). On this basis, it is tempting to speculate that average CR may be faster in the tropical species studied here. But confirmation of any such trend must await further comparison over a wider range of feeding conditions. Present measures did not include all feeding conditions experienced by each species in their natural environments.

Although present experimental ranges of food availability differed between some species (refer to 'Materials and methods'), there are certain clear findings of interest. A key finding from the present study has been that average REP (fraction) of approximately 3 to $8 \mu \mathrm{m}$ equivalent spherical diameter were essentially similar in all 5 species, but that average retention efficiencies for the largest filtered particle size class with an average diameter of $16 \mu \mathrm{m}$ were significantly lower than for the smallest particles with an average diameter of approximately $3 \mu \mathrm{m}$ in Perna viridis, Crassostrea belcheri and Crassostrea iradelei (Fig. 2). Many previous investigations of particle retention efficiency in a variety of filter-feeding bivalve shellfish have reported that REP generally increased to constant maxima at the largest particle diameters (e.g. Hawkins \& Bayne 1992, Barillé et al. 1993). However, it has also been observed that REP decreased with increasing particle diameter above about $8 \mu \mathrm{m}$ in the scallop Placopecten magellanicus from temperate latitudes (Cranford \& Grant 1990. MacDonald \& Ward 1994). MacDonald \& Ward (1994) suggested that this may have been an artefact caused by the lower number of particles in larger size classes. We do not agree that such an artefact occured in our work here. Differences were statistically significant (refer to 'Results'). In addition, independent measures of the average $( \pm 2 \mathrm{SE}$ ) REO (fraction) show that the organic contents of matter filtered by $P$. viridis $(0.99 \pm$ $0.67)$, C. belcheri $(0.35 \pm 0.21)$ and $C$. iradelei $(0.36 \pm$ $0.23)$ were all significantly higher than the organic content of available seston. These are the same 3 species that showed reduced retention of the largest filtered particle size class. Yet in both Saccostrea cuccuJata and Pinctada margarifera, we observed neither any reduced retention of larger particles nor any net organic enrichment of filtered matter. Most importantly, these collective findings are consistent with past studies establishing that the smallest suspended particles have highest organic contents within natural seston from both temperate and tropical environments (Defossey \& Hawkins 1997), explaining how reduced retention of larger particles may result in the greater proportional retention of organic matter. In a related phenomenon, Defossey \& Hawkins (1997) reported differential size-dependent rejection of larger particles within pseudofaeces from the temperate filter-feeding bivalves Mytilus edulis, Ruditapes philippinarum and Tapes decussatus, pointing out how rejection observed on the basis of particle size alone may effect the organic enrichment of natural filtered seston. It seems then, that larger particles may be relatively 'undesirable', for which both a declining retention efficiency on the gill and an increasing efficiency of rejection as pseudofaeces may additively effect the pre-ingestive selection of organically rich matter.

We suspect that methodological differences may explain the contrast between past reports that REP increased to constant maxima with increasing particle diameter, and our present findings in Perna viridis, Crassostrea belcheri and Crassostrea iradelei, including past findings in Placopecten magellanicus (Cranford \& Grant 1990, MacDonald \& Ward 1994). Both our present work and that in $P$. magellanicus compared particle-size distributions within the inflow and outflow from separate trays that each contained 1 shell- 
fish, when high throughflows ensured that test individ uals did not remove more than $30 \%$ of the particles suspended within previously unused seawater. In contrast, other measures of particle retention efficiency in filter-feeding bivalves have all monitored the relative decline of different size-fractions whilst experimental individuals were maintained within static containers of seawater, or with very slow throughflows (refer Barillé et al. 1993 for summary of past literature). Under such circumstances of limited throughflow, repeated refiltering of water may result in the ultimate removal of all larger particles, and possible overestimation of the associated retention efficiencies.

Negative influences of TPM have been recorded upon retention efficiencies for small particles in temperate species that include Crassostrea virginica (Loosanof \& Engle 1947), Mytilus edulis (Davids 1964), Agopecten irradians (Palmer \& Williams 1980), Ostrea edulis (Wilson 1983) and Crassostrea gigas (Barillé et al. 1993). It is possible that the same may have occurred in the present species over larger ranges of seston availability than were studied here. However, whether particle retention efficiency varies within and/or between species, our findings suggest that variation is of both physiological and ecological importances. Compared with the available seston, the organic content of filtered particles was increased by averages of about $35 \%$ in Crassostrea belcheri and Crassostrea iradelei, and by an average of as much as $99 \%$ in Perna viridis (Table 2). Differential retention of filtered particles has been well established using flow cytometry in many shellfish species (e.g. Bougrier et al. 1997, and references therein). For these reasons, it may not be acceptable to calculate FR $\left(\mathrm{mg} \mathrm{h}^{-1}\right)$ indirectly as the product of $\mathrm{CR}\left(\mathrm{l} \mathrm{h}^{-1}\right)$ and food availability measured either as TPM (mg l-1) or POM $\left(\mathrm{mg} \mathrm{l}^{-1}\right)$.

In addition to establishing differential retention of filtered particles on the gill, we have shown that all 5 species studied here were able selectively to enrich the organic content of ingested matter relative to filtered matter, preferentially rejecting particles of higher inorganic content as pseudofaeces prior to ingestion. Previous work in temperate species feeding upon the same natural seston in the bay of Marennes-Oléron, France, has shown that efficiencies of that selection (NOSE) in the cockle Cerastoderma edule, the oyster Crassostrea gigas and the mussel Mytilus edulis each varied positively with both the organic content of available seston (OCS) and the mass of seston filtered $\mathrm{h}^{-1}$ (FR) (Hawkins et al. 1998). Stepwise multiple regressions confirmed that NOSE increased in strong positive relations with OCS alone in Perna viridis, Crassostrea belcheri and Saccostrea cucculata studied here. It is uncertain whether NOSE declines with OCS due to a relatively constant enrichment of pseudofaeces by mucus (Hawkins et al. 1996), or because algae are more easily transported on ciliary currents to the mouth, and may be proportionally more abundant than silt in seston of higher OCS (Jørgensen 1996). In either case, we suspect that the lack of any significant additional influence of FR on NOSE may be ecologically relevant in these tropical species. In temperate species, increased NOSE at faster FR is an important response which helps to maintain nutrient acquisition independent of fluctuations in seston availability and composition, because the general negative relation between OCS and TPM (Fig, 1) means that filtered material is increasingly 'diluted' by silt as the concentrations of available seston increase to levels that often exceed $200 \mathrm{mg} \mathrm{TPM} \mathrm{l}^{-1}$ (Hawkins et al. 1996). This response may not be as important in tropical waters, where TPM is on average lower, and where seasonal fluctuations in seston availability are on average less extreme

The physiological consequences of NOSE were amplified by a common positive exponential relation between NAEIO (fraction) and OCI (fraction) (Fig. 6) Similar relations have previously been observed within Cerastoderma edule, Crassostrea gigas and Mytilus edulis feeding upon natural seston in temperate waters; the relation observed in $M$. edulis was similar to the common relation observed here (Fig. 6) (Hawkins et al. 1998). The reason for these relations is presently unclear. Hawkins et al. (1996) suggested that dependence of NAEIO on OCI may stem from the metabolic faecal losses that are incurred through normal digestive processes, and which appear reasonably constant per unit of total mass ingested (Hawkins et al. 1990), thereby exerting proportionally greater influence upon net efficiencies of absorption from ingested matter of increasingly lower organic contents. Alternatively, it has been proposed that lower efficiencies of organic selection may result in lower digestibility of the organic matter ingested from available seston of low OCS (Jørgensen 1996).

Resulting absorption and growth in Perna viridis may have been close to their maxima across the full range of experimental seston availability, as indicated by (1) the reduction in CR to values that approximated zero when exposed to more than about $2.5 \mathrm{mg} \mathrm{POM} \mathrm{l}^{-1}$ (Fig. 3), and (2) the lack of any clear change in NOAR over the full range of experimental TPM (Fig. 7). This suggests that $P$. viridis was well-adapted to the ranges of seston abundance and quality experienced in the Merbok mangrove estuary, and may perform equally well in less turbid water with lower POM. However, in Crassostrea belcheri exposed to identical ranges of TPM and OC (refer to 'Materials and methods'), there was no decline in CR ( $p>0.05)$ and a linear increase in NOAR with TPM (Fig. 7). Apparently, C. belcheri would have ingested more and grown faster at higher 
food availabilities than were experienced here, as is consistent with the natural distribution of this fastgrowing oyster in turbid waters (e.g. Yoo \& Ryu 1984).

NOAR (mg organics $\mathrm{g}^{-1} \mathrm{~h}^{-1}$ ) represents the energy available for metabolism and production. The average NOAR of $21.5 \mathrm{mg}$ organics $\mathrm{h}^{-1} \mathrm{~g}^{-1}$ that we report here in Perna viridis represents an organic ingestion rate of nearly $52 \%$ of total dry soft tissue per day. Shafee (1979) reported that the energy deposited within tissue (= net growth or production) represented a maximum of $56 \%$ of the energy absorbed in $P$. viridis. Assuming that the energy content of absorbed organic matter was $7.25 \mathrm{~J} \mathrm{mg}^{-1}$ (Hawkins et al. 1996), the resulting energy available for production in $P$. viridis of $1 \mathrm{~g}$ dry soft tissue may be calculated as $[0.56 \times(21.5 \times 7.25)]=$ $87 \mathrm{~J} \mathrm{~h}^{-1}$. Mussel tissue has an energy content of about $23.5 \mathrm{~J} \mathrm{mg}^{-1}$ (Slobodkin \& Richman 1961), so that the present estimate of average NOAR indicates potential net growth of about $9 \%$ soft tissue $\mathrm{d}^{-1}$ in $P$. viridis of $1 \mathrm{~g}$ dry soft tissue. Equivalent calculations based upon measures of NOAR in the temperate mussel Mytilus edulis indicated that maximal growth associated with apparent saturation of digestive processes represented only $4.0 \% \mathrm{~g}^{-1}$ dry soft tissue $\mathrm{d}^{-1}$, which matched seasonal maxima in the natural environment (Hawkins et al. 1997). This contrast is consistent with observations that shell length in $P$. viridis may increase by an average of as much as $13 \mathrm{~mm} \mathrm{mo} \mathrm{mo}^{-1}$ during growth from seed (<30 $\mathrm{mm}$ ) to marketable size (>75 mm) (Kuriakose 1980, Rangarajan \& Narasimham 1980), compared with a maximum of only $7 \mathrm{~mm} \mathrm{mo}^{-1}$ in $M$. edulis and various other mussel species of comparable size from temperate waters (Hickman 1979).

Fast growth in Perna viridis stems from a combination of interrelated differences in feeding behaviour. Maximal CR recorded in $P$. viridis at our lowest seston availabilities of $\mathrm{POM}<1 . \mathrm{mg} \mathrm{l}^{-1}$ averaged $13.2 \pm 7.0 \mathrm{l}$ $\mathrm{h}^{-1} \mathrm{~g}^{-1}(\mathrm{n}=9, \pm 2 \mathrm{SE}$ ), which was more than double average maxima of less than $5 \mathrm{l} \mathrm{h}^{-1} \mathrm{~g}^{-1}$ recorded over the same range of natural POM in the temperate mussel Mytilus edulis (e.g. Hawkins et al. 1996, 1998) (Fig. 3). Further, the average ( \pm 2 SE) REO of $0.99 \pm$ 0.67 in $P$. viridis was significantly greater than in all 4 oyster species (Table 2), and the average NOSE of 0.63 \pm 0.03 in $P$. viridis was significantly higher than has previously been reported in any species to date (e.g. Hawkins et al. 1996, 1998, Iglesias et al. 1996, Soletchnik et al. 1996, Bacon et al. 1998).

As in Perna viridis, present findings suggest that organic absorption and growth in both Saccostrea cucculata and Pinctada margarifera were already maximal at our lowest experimental seston concentrations of about $10 \mathrm{mg}$ TPM $\mathrm{l}^{-1}$ (Fig. 7). S. cucculata is generally found on rocky or firm substrata in relatively open waters, whereas Pinctada species are often character- istic of other clearer water, including coral reefs. Certainly, compared with other filter-feeding bivalve shellfish from tropical waters, Pinctada species grow very slowly, with an annual increase in shell length of less than $3 \mathrm{~cm}$ (Yoo et al. 1986, Numaguchi 1996). This was reflected by the average NOAR of $1.3 \pm 0.9 \mathrm{mg} \mathrm{h}^{-1}$ recorded in Pinctada margarifera of $1 \mathrm{~g}$ dry soft tissue here, and which was only $6 \%$ of the average NOAR recorded in $P$. viridis (Table 2). CR in $P$. margarifera was comparable with the other studied species, but with little pre-ingestive selection, as REO was insignificant, and NOSE only averaged 0.22 \pm 0.09 (Table 2). Significantly, Ward \& MacDonald (1996) did not observe selective rejection of inorganic matter in the sub-tropical pearl oyster Pinctada imbricata, which appeared to produce pseudofaeces solely as a means of regulating ingestion rate. Our collective findings therefore suggest that Pinctada spp. may not be welladapted for the differential retention or rejection of POM, which constitutes at least part of the physiological basis for comparatively slow growth.

In conclusion, we have shown that key interrelations between component processes of nutrient acquisition in tropical bivalves were similar to those among temperate species. Our findings also establish significant differences in the feeding behaviour of functionally similar species from tropical latitudes. Although subtle, these differences are likely to be of ecological consequence, reflecting the importance of species diversity. Further studies over complete natural ranges of seston availability and composition are required before the development of models that predict relative impacts of different bivalve filter-feeders upon particle fluxes, nutrient dynamics and community structure.

Acknowledgements. This work represents part of Strategic Research Project 3 ('Marine Biodiversity') of the Plymouth Marine Laboratory, a component of the UK Natural Environment Research Council, and was supported by the UK Darwin Initiative funding programme. We also thank The Fisheries Research Institute of Penang for use of their raft in the Merbok mangrove system, Balasubramaniam s/o Kandasamy for general experimental help, Yahya B. Hussin for help and hospitality whilst working in the field, and 3 anonymous review editors for their comments on the manuscript.

\section{LITERATURE CITED}

Bacon GS, MacDonald BA, Ward JE (1998) Physiological responses of infaunal (Mya arenaria) and epifaunal (Placopecten magellanicus) bivalves to variations in the concentration and quality of suspended particles. I. Feeding activity and selection. J Exp Mar Biol Ecol 219:87-103

Barillé L. Héral M, Barillé-Boyer AL (1997) Modélisation de l'écophysiologie de l'huitre Crassostrea gigas dans un environnement estuarien. Aquat Living Resour 10:31-48 Barillé L, Prou J, Héral M, Bougrier S (1993) No influence of 
food quality, but ration-dependent retention efficiencies in the oyster Crassostrea gigas. J Exp Mar Biol Ecol 171. 91-106

Bayne BL (1998) The physiology of suspension feeding by bivalve molluscs: an introduction to the Plymouth 'TROPHEE' workshop. J Exp Mar Biol Ecol 219:1-19

Bayne BL, Hawkins AJS (1992) Ecological and physiological aspects of herbivory in benthic suspension-feeding molluscs. In: John DM, Hawkins SJ, Price JH (eds) Plantanimal interaction in the marine benthos. Systematics Association Spec Vol No. 46. Clarendon Press, Oxford, p 265-288

Bayne BL, Iglesias JIP, Hawkins AJS, Navarro E. Héral M, Deslous-Paoli JM (1993) Feeding behaviour of the mussel, Mytilus edulis L.; responses to variations in both quantity and organic content of seston. J Mar Biol Assoc UK 73: $813-829$

Bayne BL, Newell RC (1983) Physiological energetics of marine molluscs. In: Wilbur KM, Saleuddin AS (eds) The Mollusca, Vol 4. Academic Press, New York, p 407-51.5

Bougrier S, Hawkins AJS, Héral M (1997) Preingestive selection of different microalgal mixtures in Crassostrea gigas and Mytilus edulis, analysed by flow cytometry. Aquaculture 150:1.23-134

Brohmanonda P, Mutaransit K (1988) Oyster culture in Thailand. In: McCoy EW, Chongpeepien T (eds) Bivalve mollusc culture research in Thailand. ICLARM (Int Cent Living Aquat Resour Manage) Tech Rep 19:31-39

Cranford PJ, Gordon DC Jr (1992) The influence of dilute clay suspensions on sea scallop (Placopecten magellanicus) feeding activity and tissue growth. Neth J Sea Res 30: $107-120$

Cranford PJ, Grant J (1990) Particle clearance and absorption of phytoplankton and detritus by the sea scallop Placopecten magellanicus (Gmelin). J Exp Mar Biol Ecol 137: $105-121$

Dame RF (1993) The role of bivalve filter feeder material fluxes in estuarine ecosystems. In: Dame RF (ed) Bivalve filter feeders in estuarine and coastal ecosystem processes. Springer-Verlag, Berlin, p 245-270

Davids C (1964) The influence of suspensions of micro-organisms of different concentrations on the pumping and retention of food by the mussel (Mytilus edulis L.). Neth J Sea Res 2:233-249

Defossey JM, Hawkins AJS (1997) Selective feeding in shellfish: size-dependent rejection of large particles within psuedofaeces from Mytilus edulis, Ruditapes philippinarum and Tapes decussatus. Mar Biol 129:139-148

Doering PH, Oviatt CA (1986) Application of filtration rate models to field populations of bivalves: an assessment using experimental mesocosms. Mar Ecol Prog Ser 31: $265-275$

Foster-Smith RL (1975) The effect of concentration of suspension and inert material on the assimilation of algae by three bivalves. J Mar Biol Assoc UK 55:411-418

Hawkins AJS, Bayne BL (1992) Physiological processes, and the regulation of production. In: Gosling $E$ (ed) The mussel Mytilus: ecology, physiology, genetics and culture. Elsevier Science Publishers BV, Amsterdam, p 171-222

Hawkins AJS, Bayne BL, Bougrier S, Héral M, Iglesias JIP Navarro E, Smith RFM, Urrutia MB (1998) Some general relationships in comparing the feeding physiology of suspension-feeding bivalve molluscs. J Exp Mar Biol Ecol 219:87-103

Hawkins AJS, Navarro E, Iglesias JIP (1990) Comparative allometries of gut content, gut passage time and metabolic faecal loss in Mytilus edulis and Cerastoderma edule. Mar
Biol 105:197-204

Hawkins AJS, Smith RFM, Bayne BL, Héral M (1996) Novel observations underlying fast growth of suspension-feeding shellfish in turbid environments: Mytilus edulis. Mar Ecol Prog Ser 131:179-190

Hawkins AJS, Smith RFM, Bougrier $S$, Bayne BL, Héral M (1997) Manipulation of dietary conditions for maximal growth in mussels, Mytilus edulis L., from the MarennesOléron Bay, France. Aquat Living Res 10:13-22

Héral M (1993) Why carrying capacity models are useful tools for management of bivalve molluscs culture. In: Dame RF (ed) Bivalve filter feeders in estuarine and coastal ecosystem processes. Springer-Verlag, Berlin, p 455-478

Herman PMJ (1993) A set of models to investigate the role of benthic suspension feeders in estuarine ecosystems. In: Dame RF (ed) Bivalve filter feeders in estuarine and coastal ecosystem processes. Springer-Verlag, Berlin, p $421-454$

Hickman RW (1979) Allometry and growth of the greenlipped mussel Perna canaliculus in New Zealand. Mar Biol 51:311-327

Iglesias JIP, Navarro E, Alvarez Jorna P, Armentia I (1992) Feeding, particle selection and absorption in cockles Cerastoderma edule (L.) exposed to variable conditions of food concentration and quality. J Exp Mar Biol Ecol 162 $177-198$

Iglesias JIP, Urrutia MB, Navarro E, Alvarez-Jorna P, Larretxea X, Bougrier S, Héral M (1996) Variability of feeding processes in the cockle Cerastoderma edule (L.) in response to changes in seston concentration and composition. J Exp Mar Biol Ecol 197:121-143

Jarayabhand P. Thavornyutikarn M (1995) Realized heritability estimation on growth rate of oyster, Saccostrea cucullata Born, 1778. Aquaculture 138:111-118

Jorgensen $C B$ (1996) Bivalve filter feeding revisited. Mar Ecol Prog Ser 142:287-302

Kuriakose PS (1980) Open sea raft culture of green mussel at Calicut. In: Coastal aquaculture: mussel farming, progress and prospects, Vol 29. Cent Mar Fish Res Inst, Cochin, p 33-38

Loosanoff VL, Engle JB (1947) Effect of different concentrations of microorganisms on the feeding of oysters $(O$. virginica). Fish Bull Fish WildI Serv US 51:31-57

MacDonald BA, Bacon GS, Ward JE (1998) Physiological responses of infaunal (Mya arenaria) and epifaunal (Placopecten magellanicus) bivalves to variations in the concentration and quality of suspended particles. II. Absorption efficiency and scope for growth. J Lxp Mar Biol Ecol 219:127-141

MacDonald BA, Ward JE (1994) Variation in food quality and particle selectivity in the sea scallop Placopecten magellanicus (Mollusca: Bivalvia). Mar Ecol Prog Ser 108: $251-264$

Mahlenberg F, Riisgård HU (1979) Filtration rate, using a new indirect technique, in thirteen species of suspension-feeding bivalves. Mar Biol 54:143-147

Navarro E, Iglesias JIP, Ortega MM (1992) Natural sediment as a food source for the cockle Cerastoderma edule (L.): effect of variable particle concentration on feeding, digestion and the scope for growth. J Exp Mar Biol Ecol 156: $69-87$

Navarro E, Iglesias JIP, Ortega MM, Larretxea X (1994) The basis for a functional response to variable food quantity and quality in cockles Cerastoderma edule (Bivalvia, Cardiidae). Physiol Zool 67:468-496

Navarro E, Iglesias JIP, Perez Camacho A, Labarta U (1996) The effect of diets of phytoplankton and suspended bot- 
tom material on feeding and absorption of raft mussels (Mytilus galloprovincialis Lmk). J Exp Mar Biol Ecol 198: $175-189$

Navarro E, lglesias JIP, Urrutia MB, Parra J (1997) Simulating physiological responses of cockles (Cerastoderma edule) to variable conditions within estuarine media. Aquat Living Res 10:59-66

Newell CR, Shumway SE (1993) Grazing of natural particulates by bivalve molluscs: a spatial and temporal perspective. In: Dame RF (ed) Bivalve filter feeders in estuarine and coastal ecosystem processes. Springer-Verlag, Berlın, p $85-148$

Numaguch K (1996) A review on the feeding ecology and food environment of the Japanese pearl oyster, Pinctada fucata martensii. Bull Natl Res Inst Fish Sci 8:123-138

Palmer RE, Williams RE (1980) Effect of particle concentration on filtration efficiency of the bay scallop Argopecten irradians and the oyster Crassostrea virginica. Ophelia 19 $163-174$

Rangarajan K, Narasimham KA (1980) Mussel farming on the east coast of India. In: Coastal aquaculture: mussel farming, progress and prospects, Vol 29. Cent Mar Fish Res Inst, Cochin, p 39-41

Riisgård HU (1988) Efficiency of particle retention and filtration rate in 6 species of northeast American bivalves. Mar Ecol Prog Ser 45:217-223

Shafee MS (1979) Ecological energy requirements of the green mussel, Perna viridis Linnaeus from Ennore estuary, Madras. Oceanologica Acta 2:69-74

Sivalingam PM (1982) Exploitation of shellfish mariculture in Malaysia: a highly productive marine protein resource for developing Third World countries. Atlantica 5:111

Slobodkin LB, Richman S (1961) Calories/gm in species of

Editorial responsibility: Otto Kinne (Editor),

Oldendorf/Luhe, Germany animals. Nature 191:299

Smaal AC, Prins TC (1993) The uptake of organic matter and the release of inorganic nutrients by bivalve suspension feeder beds. In: Dame RF (ed) Bivalve filter feeders in estuarine and coastal ecosystem processes. SpringerVerlag, Berlin, p 271-298

Soletchnik P, Goulletquer P, Héral M, Razet D, Geairon P (1996) Évaluation du bilan énergétique de l'huître creuse, Crassostrea gigas, en baie de Marennes-Oléron (France). Aquat Living Res 9:65-73

Urrutia MB, Iglesias JIP, Navarro E, Prou J (1996) Feeding and absorption in Cerastoderma edule under environmental conditions in the bay of Marennes-Oléron (Western France). J Mar Biol Assoc UK 76:431-450

Ward JE, MacDonald BA (1996) Pre-ingestive feeding behaviours of two sub-tropical bivalves (Pinctada imbricata and Arca zebra): responses to an acute increase in suspended sediment concentration. Bull Mar Sci 59:417-432

Widdows J, Fieth P, Worrall CM (1979) Relationships between seston, available food and feeding activity in the common mussel Mytilus edulis. Mar Biol 50:195-207

Wildish DJ, Saulnier AM (1993) Hydrodynamic control of filtration in Placopecten magellanicus. J Exp Mar Biol Erol $174: 65-82$

Wilson JH (1983) Retention efficiency and pumping rate of Ostrea edulis in suspensions of Isochrysis galbana. Mar Ecol Prog Ser 12:51-58

Yoo SK, Chang YJ, Lim HS (1986) Growth comparison of pearl oyster, Pinctada fucata between two culturing areas. Bull Korean Fish Soc 19:593-598

Yoo SK, Ryu HY (1984) Comparative morphological characteristics of mangrove oysters. Bull Korean Fish Soc 17 : $321-326$

Submitted: November 20, 1997; Accepted: March 30, 1998

Proofs received from author(s): May 15, 1998 